\title{
Molecular analysis of ras oncogenes in CIN III and in stage I and II invasive squamous cell carcinoma of the uterine cervix
}

\author{
J J O'Leary, R J Landers, I Silva, V Uhlmann, M Crowley, I Healy, K Luttich
}

\begin{abstract}
Aim-To examine the prevalence of genital type human papilloma virus (HPV) and mutations at codons 12,13 , and 61 in $\mathrm{H}, \mathrm{Ki}$, and $\mathrm{N}$-ras in CIN III and early invasive squamous cell carcinomas of the cervix.

Methods-Prevalence of HPV was examined in 20 CIN III and 20 stage I and II cervical carcinomas, using non-isotopic in situ hybridisation (NISH) and solution phase polymerase chain reaction (PCR). In addition, mutations at codons 12, 13, and 61 were examined in $\mathrm{H}, \mathrm{Ki}$, and $\mathrm{N}$-ras in these CIN III and early invasive squamous cell carcinomas, to assess the prevalence of ras gene point mutations and to define where in the pathobiology of squamous cell carcinoma such events occur. A non-isotopic PCR/RFLP assay was used to define these mutations.
\end{abstract}

Results-Of the 20 CIN IIIs examined, 19 contained HPV 16 DNA sequences by PCR and NISH. Dual infection was not uncovered. The 20 early (stage I and II) invasive squamous cell carcinomas showed predominant HPV 16 positivity (17/20), with one case HPV 18 positive, confirmed on PCR and NISH. Activating mutations were not identified in any of the CIN III cases. Only one stage I, HPV 16 positive carcinoma showed an activating mutation in $\mathrm{H}$-ras codon 12, which was not present in adjacent normal ectocervical mucosa from the same patient.

Conclusions-ras Activation does not appear to occur in conjunction with HPV infection, particularly of HPV 16 infected high grade cervical intraepithelial neoplasia, or to occur commonly in early cervical squamous cell carcinoma. The postulated model of HPV linked carcinogenesis suggests malfunctional control of viral transcription as a necessary component of neoplastic progression. It is also clear that host gene alterations are equally necessary for HPV linked carcinogenesis to occur.

(F Clin Pathol 1998;51:576-582)

Keywords: ras; human papilloma virus; cervical carcinoma; CIN III

Correspondence to: Dr J J O'Leary, Department of Pathology, The Coombe Women's Hospital, Dublin, Republic of Ireland.

Accepted for publication 5 February 1998

There are three members of the ras oncogene family. N-ras is located on chromosome 1 (1p21p32), H-ras on chromosome 11 (11p15.1-p15.5), and K-ras on chromosome 12 (12p12.1-pter). ${ }^{1}$ Each of these three genes contains four coding exons which specify homologous proteins of $21 \mathrm{kDa}$ and a 5' non-coding exon. ${ }^{2}$ In addition, two pseudogenes, H-ras-2 and K-ras-1, have been identified and characterised in rats and humans; ${ }^{3}$; these are mapped to the $\mathrm{X}$ chromosome to the 6p12-p23 locus. ${ }^{3}$

The protein encoded by the ras genes binds guanosine triphosphate (GTP) and guanosine diphosphate (GDP) with high affinity and are known to possess GTPase activity. ${ }^{2}$ Such ras proteins share biochemical properties with " $\mathrm{G}$ proteins," which are known to play a role in signal transduction pathways from membrane bound receptors to adenylate cyclase. ${ }^{4}$ In fact, certain domains of the ras proteins show significant sequence homology with the $\alpha$ subunit of $G$ proteins such as $G_{5}$, which is known to activate adenylate cyclase directly in response to $\beta$ adrenergic stimuli, making ras proteins involved in signal transduction. ras Proteins probably exist in equilibrium in the cell between an active and an inactive stage. Inactive forms bind GDP. ras Proteins will remain inactive until they receive a stimulus from another protein/receptor upstream of a putative pathway of signal transduction. Such a stimulus results in the exchange of GDP for GTP, followed by a conformational alteration of inactive ras to active ras. Once interaction between the active ras proteins and the effector has taken place, immediate deactivation would occur. This is achieved by the intrinsic GTPase activity catalysing the hydrolysis of GTP and thus returning the ras proteins to the inactive GDP bound state. Mutation occurring in the ras genes shifts the normal equilibrium to the active form. Such stabilisation phenomena would result in continuous signal transduction and subsequently malignant transformation.

Theoretically, ras stabilisation can be achieved by mutations that inhibit the intrinsic GTPase activity of ras proteins, increase the exchange rate between GDP and GTP, or induce an active conformational change that does not require binding of guanine nucleotides. Indeed, normal ras genes if overexpressed also induce malignant transformation by producing many molecules in the GTP bound active state. Experimental evidence now indicates that inhibition of GTPase activity is the preferred mechanism of activation of ras oncogenes. $^{56}$
Activation of ras genes may occur through (1) mutations in the coding regions and (2) enhanced expression. Mutations in the three ras oncogenes (H-ras, K-ras, and N-ras) are 
known to occur in the codons for amino acids 12,13 , and 61. Additionally, when $\mathrm{H}$-ras is exposed to bisulphite particular mutations in codons $12,13,59$, and 63 result, which shows that codons 59 and 63 are also potential targets for activating mutations. ${ }^{2}$ Besides these two sites, mutations in codons 116 and 119 can also activate the ras gene. ${ }^{7}$

Enhanced expression can be obtained by the insertion of a strong promoter or enhancer in the vicinity of the ras gene, ${ }^{28}$ by amplification of the normal proto-oncogene, ${ }^{9}$ or by deletion of the first (non-coding) exon. ${ }^{10}$ Mutations at codons 12,13 , and 61 are likely to lead to loss of GTPase activity which results in a constitutively activated ras oncogene.

Somatic deletions and mutations of $\mathrm{H}$-ras gene in human cervical cancers have been described by Riou et $a l,{ }^{11}$ who examined the c-H-ras-1 locus in cervical cancers and described loss of one allele at this locus in $36 \%$ of heterozygous tumours and a mutation on codon 12 in $24 \%$ of tumours at an advanced stage.

These investigators also demonstrated amplification of c-myc and H-ras. ${ }^{12}$ In addition, increased expression of the ras p21 gene has been found in cervical carcinoma, using the Y13-295 monoclonal antibody, ${ }^{13}$ showing a higher staining intensity in malignant tumour cells than in benign or premalignant lesions. It has been suggested that serological testing for p21 may have potential for monitoring disease activity in patients with cervical carcinoma. ${ }^{14}$

$\mathrm{H}$-ras point mutations have been implicated in the pathogenesis of cervical neoplasia. In contrast, a large study of K-ras activation in neoplasms of the human female reproductive tract did not show any point mutational activity in cervical carcinomas. ${ }^{15}$ Interestingly, a low incidence of ras oncogene activation in human squamous cell carcinomas from other sites has been reported by Rumsby et al. ${ }^{16}$

In anogenital neoplasia, mutations of K-ras at codon 12 have been shown in anal carcinomas not infected with human papilloma virus (HPV). Hiorns et al suggest that ras activation does not appear to be a common event

Table 1 Summary of ras gene assays for H-ras

\begin{tabular}{|c|c|c|c|c|}
\hline \multirow[b]{2}{*}{ Gene } & \multirow[b]{2}{*}{ Enzyme } & \multicolumn{3}{|c|}{ Fragment size } \\
\hline & & Undigested & Mutant & Normal \\
\hline \multicolumn{5}{|c|}{$\begin{array}{l}\text { H5': 5'GAGACCCTGTAGGAGGACCC3' } \\
\text { H3': 5'GGGTGCTGAGACGAGGGACT3' }\end{array}$} \\
\hline \multicolumn{5}{|c|}{$\begin{array}{l}\text { H12S: 5'GCAGGAGACCCTGTAGGAGGAC3' } \\
\text { H13A Hph: 5'GTCAGCGCACTCTTGCCCTCA3' }\end{array}$} \\
\hline H-ras-61 & $\begin{array}{l}\text { AlwNI }{ }^{\mathrm{b}} \\
(\mathrm{CAGNNNCTG})\end{array}$ & 177 & 177 & $160+(17)$ \\
\hline \multicolumn{5}{|c|}{$\begin{array}{l}\text { Nested PCR: } \\
\text { H-61S: 5'ATGAGAGGTACCAGGGAGAG3' } \\
\text { H-61A: 5'TCACGGGGTTCACCTGTACT3' } \\
\text { H-61AAlw: 5'CGCATGGCGCTGTACAGCTC3'^ }\end{array}$} \\
\hline
\end{tabular}

^Mismatched nucleotides in the primers are underlined.

${ }^{a} \mathrm{Kahn}$ et al (reference 22).

${ }^{\mathrm{b}}$ Mitsudomi et al (reference 23).

MspI from Gibco BRL; HpHI from New England Biolabs; AlwNI from Sigma. in the genesis of such tumours and if it does occur it does not appear to cooperate with HPV. $^{17}$

Another common HPV associated tumour, oesophageal carcinoma, has also been examined for point mutations at codons 12, 13, and 61 of the ras oncogenes. Victor et al failed to show any evidence of mutations in these codons in squamous cell carcinomas of the oesophagus in South Africa. ${ }^{18}$

In this study, we examine mutations in these codons in $\mathrm{H}, \mathrm{Ki}$, and $\mathrm{N}$-ras in cervical intraepithelial neoplasia (CIN) grade III and early invasive squamous cell carcinomas of the cervix, to assess the prevalence of such mutations and to examine where in the pathobiology of squamous cell carcinoma such events occur.

\section{Methods}

MATERIALS

Archival paraffin wax embedded tissues of 20 CIN III and 20 stage I and II invasive squamous cell carcinomas were retrieved from the files of the department of pathology, University College Cork, Ireland. Six of the carcinoma group had coexistent CIN III in the resection specimen. Control histologically normal ectocervical tissue was examined in lesions (where possible) in order to assess the prevalence of genotypic geographical change in adjacent epithelium.

\section{HPV DNA IN SITU HYBRIDISATION}

Three $5 \mu \mathrm{m}$ sections (selected from three different areas of the tumour) were cut onto APES coated glass slides (PH106, C A Hendley, Essex, UK). In addition, two areas from the included cervix were also examined.

Tissue dewaxing was carried out using xylene and rehydration through a graded alcohol series. Proteolytic digestion was carried out using $0.5 \mathrm{mg} / \mathrm{ml}$ proteinase $\mathrm{K}$ in proteinase $\mathrm{K}$ buffer $(50 \mathrm{mM}$ Tris $\mathrm{HCl}, \mathrm{pH} 7.6+5 \mathrm{mM}$ EDTA) at $37^{\circ} \mathrm{C}$ for 10 minutes. For alkaline phosphatase detection, slides were immersed in $20 \%$ (vol $/ \mathrm{vol}$ ) aqueous acetic acid at $4^{\circ} \mathrm{C}$ for 15 seconds. For peroxidase detection, slides were immersed in 3\% sodium azide/hydrogen peroxide to abolish endogenous peroxidase activity. Slides were then washed in phosphate buffered saline for five minutes. A postfixation step was not carried out. Dehydration of the sections then took place through graded alcohols to water.

Cloned HPV probes $(6,11,16,18,31,33)$ (genital types; gifts of Harald Zur Hausen) were labelled with biotin or digoxigenin using a standard nick translation protocol. ${ }^{19}$ Probes were initially prepared at a concentration of $200 \mathrm{ng} / \mathrm{ml}$.

The hybridisation buffer contained $(2 \times$ SSC ( $\mathrm{NaCl} /$ sodium citrate), $5 \%$ dextran sulphate, $0.2 \%$ dried milk powder containing no vegetable extracts, and $50 \%$ formamide). Approximately 10-20 ng of the appropriate probe in the hybridisation buffer was applied to the centre of each well on the PH106 slides. Hybridisation was carried out as previously described. ${ }^{12}$ 
Table 2 Summary of ras gene assays for K-ras

\begin{tabular}{|c|c|c|c|c|}
\hline \multirow[b]{2}{*}{ Gene } & \multirow[b]{2}{*}{ Enzyme } & \multicolumn{3}{|c|}{ Fragment size } \\
\hline & & Undigested & Mutant & Normal \\
\hline K-ras-12 & Bst NI (CC GG) & 157 & 143 & 114 \\
\hline $\begin{array}{l}\text { K12S1: } \\
\text { K12A1: }\end{array}$ & $\begin{array}{l}\text { 5'ACTGAATATAAACTTC } \\
\text { 5'TCAAAGAATGGTCCT }\end{array}$ & $\begin{array}{l}\text { GTAGTTG } \\
\text { AAC3' }\end{array}$ & T3' & \\
\hline $\begin{array}{l}\text { K13 (asp) } \\
\text { K12S1: } \\
\text { K12A1: }\end{array}$ & $\begin{array}{l}\text { Hph I (GGTGA) } \\
\text { 5'ACTGAATATAAACTTC } \\
\text { 5'TCAAAGAATGGTCCT }\end{array}$ & $\begin{array}{l}157 \\
\text { GTAGTTG } \\
\text { AAC3' }\end{array}$ & 114 & 157 \\
\hline $\begin{array}{l}\text { K-ras 13 } \\
\text { K12S2: } \\
\text { K13AHae: }\end{array}$ & $\begin{array}{l}\text { Hae III (GGCC) } \\
\text { 5'CATGTTCTAATATAG' } \\
\text { 5'TATCGTCAAGGCACT }\end{array}$ & $\begin{array}{l}116 \\
\text { CA3' } \\
\text { GCCTAGC }\end{array}$ & 116 & $91+(25)$ \\
\hline $\begin{array}{l}\text { K-ras } 61 \\
\text { K61SBcl: } \\
\text { K61A: }\end{array}$ & $\begin{array}{c}\text { Bcl I (TGATCA) } \\
\text { 5'GGATATTCTCGACAC } \\
\text { 5'AATTACTCCTTAATG' }\end{array}$ & $\begin{array}{l}176 \\
\mathrm{GC}^{\mathrm{T}} \mathrm{G}\end{array}$ & $176^{\mathrm{a}}$ & $157+(19)^{a}$ \\
\hline $\begin{array}{l}\text { K61SEar: } \\
\text { K61A: }\end{array}$ & $\begin{array}{l}\text { Ear I (GAAGAG) }{ }^{c} \\
\text { 5'GGATATTCTCGACAC } \\
\text { 5'AATTACTCCTTAATG' }\end{array}$ & $\begin{array}{l}176 \\
\text { GCGT' }\end{array}$ & $176^{\mathrm{a}}$ & $151+(25)^{\mathrm{a}}$ \\
\hline
\end{tabular}

${ }^{\star}$ Mismatched nucleotides in the primers are underlined.

${ }^{\text {aS }}$ See text for details (not all mutants are uncut).

${ }^{\mathrm{b}} \mathrm{Kahn}$ et al (reference 22).

${ }^{\mathrm{c}}$ Mitsudomi et al (reference 23).

Bst NI, Hae III, Bcl I from Sigma; Hph I, Ear I from New England Biolabs.

Table 3 Summary of ras gene assays for $N$-ras

\begin{tabular}{|c|c|c|c|c|c|}
\hline \multirow[b]{2}{*}{ Gene } & \multirow{2}{*}{\multicolumn{2}{|c|}{ Enzyme }} & \multicolumn{3}{|c|}{ Fragment size } \\
\hline & & & Undigested & Mutant & Normal \\
\hline \multicolumn{2}{|c|}{ N-ras $12($ method 1$)$} & Hph I (GGTGA) ${ }^{a}$ & 70 & 70 & $59+(11)$ \\
\hline N12S1: & \multicolumn{5}{|c|}{ 5'CTGGTGTGAAATGACTGAG3' } \\
\hline N12AHph: & \multicolumn{5}{|c|}{ 5'TGTCAGTGCGCTTTTCCCAACATC3' } \\
\hline \multicolumn{2}{|c|}{ N-ras 12 (method 2$)$} & BspMI (GCAGGT) & 128 & 113 & 94 \\
\hline N12S2: & \multicolumn{5}{|c|}{ 5'ACTGAGTACAAACTGGTGGTGGTTCCAGCA3' } \\
\hline N12A2: & \multicolumn{5}{|c|}{ 5'GGGCTACCTGCGGGCCTCCACTCTATGG3' } \\
\hline N-ras 13 & & HphI (GGTGA) ${ }^{c}$ & 82 & 82 & $59+(23)$ \\
\hline N12S1: & \\
\hline N13AHph: & \multicolumn{3}{|c|}{ 5'GATTAGCTGGATTGTCAGTGCGCTTTTCCCATC3' } & & \\
\hline N-ras 61 & & MscI (TGGCCA) ${ }^{a}$ & 126 & 126 & $103+(23)$ \\
\hline N61SBal: & \multicolumn{5}{|c|}{ 5'TTGGACATACTGGATACAGCTGGC3' } \\
\hline N61A: & \multicolumn{5}{|c|}{ 5'GTTAATATCCGCAAATGACTTGC3' } \\
\hline
\end{tabular}

^Mismatched nucleotides in the primers are underlined.

${ }^{a}$ Mitsudomi et al (reference 23).

bO'Leary et al.

'O'Leary, and Mitsudomi et al (reference 22).

Hph I, BspMI from New England Biolabs; MscI from Sigma.

Following hybridisation, medium stringency washings were initially applied using $2 \times$ SSC at $60^{\circ} \mathrm{C}$ for 20 minutes, followed by $0.2 \times \mathrm{SSC}$ for $42^{\circ} \mathrm{C}$ at 20 minutes, then $0.1 \times$ SSC at room temperature for five minutes and $2 \times$ SSC at room temperature for five minutes. Higher stringency washes included $0.2 \times \mathrm{SSC}$ at $55^{\circ} \mathrm{C}$ and $60^{\circ} \mathrm{C}$ for 10 minutes and $0.1 \times \mathrm{SSC}$ at room temperature, $42^{\circ} \mathrm{C}$, and $55^{\circ} \mathrm{C}$.

The hybridisation signal was detected using one step, two step, or three step techniques as described previously. ${ }^{12}$ Colorimetric detection was achieved using an NBT/ BCIP substrate for alkaline phosphatase or AEC (Zymed kit for peroxidase; Zymed, California, USA). ${ }^{12}$ Sections were counterstained with $2 \%$ methyl green for alkaline phosphatase detection or haematoxylin for the peroxidase detection system.

Tissue controls for non-isotopic in situ hybridisation (NISH) included HPV positive cervical warts and myocardium (negative for HPV). Reaction controls included hybridisation buffer on its own, biotin/digoxigenin labelled plasmid sequences (pBR322), and an irrelevant probe (Herpes zoster virus, HZV). Labelled human placental DNA was used to check hybridisation efficiency.

Detection controls included omitting primary or secondary antibody steps and addition of the colorimetric substrate only.

SOLUTION PHASE POLYMERASE CHAIN REACTION HPV DNA sequences were derived from the EMBL genetic sequence database. HPV E6 sequences which remain intact following viral DNA integration were chosen. During oligo synthesis, a biotin reporter molecule with a 15 carbon atom linker arm was added to the 5 ' end of the oligonucleotide probe and subsequently used as an internal probe to confirm product specificity. The nucleotide sequence of the primers are as previously described. ${ }^{20}$

General HPV primers (which identify sequenced and unsequenced HPV) were also used for a pan HPV screen, unrestricted by the type specific HPV chosen above, and are as previously described. ${ }^{21}$

Sections $10 \mu \mathrm{m}$ thick were cut from the tissue blocks and placed in sterile Eppendorf tubes. Strict anticontamination protocols were adopted throughout. Nucleic acid extraction was performed using proteinase $\mathrm{K}(0.1-0.5$ $\mathrm{mg} / \mathrm{ml})$ in proteinase $\mathrm{K}$ buffer $(100 \mathrm{mM} \mathrm{NaCl}$, $10 \mathrm{mM}$ Tris $\mathrm{HCl}, 25 \mathrm{mM}$ EDTA, $0.5 \%$ SDS, $\mathrm{pH}$ 8.4). Proteinase $\mathrm{K}$ incubation was carried out for three to five days at $37^{\circ} \mathrm{C}$ with adequate mixing of samples. Proteinase $\mathrm{K}$ inactivation was then carried out at $94^{\circ} \mathrm{C}$ for 10 minutes. DNA was purified using a standard phenol chloroform isoamyl alcohol technique. Nucleic acid was precipitated using $3 \mathrm{M}$ sodium acetate and ice cold ethanol.

For type specific HPV polymerase chain reaction (PCR), the PCR solution consisted of PCR buffer $(50 \mathrm{mM} \mathrm{KCl}, 10 \mathrm{mM}$ Tris $\mathrm{HCl} \mathrm{pH}$ $8.3,1.5 \mathrm{mM} \mathrm{MgCl}_{2}, 0.01 \%$ gelatine, $200 \mu \mathrm{M}$ of each deoxynucleotide triphosphate (dNTP), $1.0 \mu \mathrm{M}$ of each primer, 2.5 units of AmpliTaq DNA polymerase, and $100 \mathrm{ng}$ of DNA template). Samples were then subjected to 40 cycles of PCR in a Perkin Elmer 480 DNA thermocycler. Cycling parameters were as follows: $94^{\circ} \mathrm{C}$ for one minute, followed by $94^{\circ} \mathrm{C}$ for one minute, $55^{\circ} \mathrm{C}$ for two minutes, $72^{\circ} \mathrm{C}$ for three minutes, by 40 cycles with a final extension set for $72^{\circ} \mathrm{C}$ for five minutes.

For general primer PCR, amplification conditions were similar except $3.5 \mathrm{mM} \mathrm{MgCl}_{2}$ was used and an annealing temperature of $40^{\circ} \mathrm{C}$ was applied.

Type specific HPV PCR products were confirmed by dot blot hybridisation, as previously described. ${ }^{20}$

ANALYSIS OF ras ONCOGENE POINT MUTATIONS Nucleic acid was extracted as above. The prevalence of ras point mutations was assessed by a PCR/RFLP analysis. Primers used for amplification of ras genes are shown in tables $1-6$.

Cell lines shown to have all six possible mutations at codon 12 of $\mathrm{Ki}$-ras and at $\mathrm{H}$-ras or $\mathrm{N}$-ras codons 12 and 61 were used as positive 
Table 4 Designed restriction fragment length polymorphisms for the detection of point mutations at codon 12 of the ras genes

\begin{tabular}{|c|c|c|c|c|c|c|c|}
\hline \multirow[b]{2}{*}{ Gene } & \multicolumn{4}{|c|}{ Sequence (codon) } & \multirow[b]{2}{*}{ Mismatch } & \multirow[b]{2}{*}{ Enzyme } & \multirow[b]{2}{*}{ Restriction site } \\
\hline & 10 & 11 & 12 & 13 & & & \\
\hline H-ras & - & GCC & GGC & GGT & - & $\mathrm{MspI}^{\mathrm{a}}$ & CCGC \\
\hline K-ras & GGA & GCT & GGT & GGC & $\underline{\text { CCT }(11)}$ & Bst $\mathrm{NI}^{\mathrm{a}}$ & $\begin{array}{l}\mathrm{T} \\
\mathrm{CC} \text { GG } \\
\mathrm{A}\end{array}$ \\
\hline Nras & GGA & GCA & GGT & GGT & $\begin{array}{l}\text { GAT (13) } \\
\text { CEA (10) }\end{array}$ & $\begin{array}{l}\mathrm{Hph} \mathrm{I}^{\mathrm{b}} \\
\mathrm{Bsp}^{\mathrm{a}}\end{array}$ & $\begin{array}{l}\text { GGTGA } \\
\text { GCAGGT }\end{array}$ \\
\hline
\end{tabular}

Sequence around codon 12 is shown; mutations are underlined. Mismatched nucleotide and its position in the primer is shown.

${ }^{a}$ Kahn et al (reference 22).

${ }^{\mathrm{b}}$ Mitsudomi et al (reference 23).

MspI from Gibco BRL; Bst NI from Sigma; Hph I and BspMI from New England Biolabs.

Table 5 Designed restriction fragment length polymorphisms (RFLP) for the detection of point mutations at codon 13 of ras genes

\begin{tabular}{lllllll}
\hline & \multicolumn{3}{l}{ Sequence (codon) } & & \\
\cline { 2 - 4 } Gene & 12 & 13 & 14 & Mismatch & Enzyme & Restriction site \\
\hline H-ras & GGC & GGT & GTG & GAG (14) & Hph I & GGTGA \\
K-ras & GGT & GGC & GTA & CTA (14) & Hae III & GGCC \\
N-ras & GGT & GGT & GTT & GAT (14) & Hph I & GGTGA \\
\hline
\end{tabular}

Sequence around codon 12 is shown; mutations are underlined. Mismatched nucleotide and its position in the primer is shown.

Origin of RFLP, Mitsudomi et al (reference 23).

Hae III from Sigma; Hph I from New England Biolabs.

Table 6 Designed restriction fragment length polymorphisms (RFLP) for the detection of point mutations at codon 61 of the ras genes

\begin{tabular}{|c|c|c|c|c|c|c|c|c|}
\hline \multirow[b]{2}{*}{ Gene } & \multicolumn{5}{|c|}{ Sequence (codon) } & \multirow[b]{2}{*}{ Mismatch } & \multirow[b]{2}{*}{ Enzyme } & \multirow[b]{2}{*}{ Restriction site } \\
\hline & 59 & 60 & 61 & 62 & 63 & & & \\
\hline H-ras & GCC & GGC & CAG & GAG & GAG & CㅁG (63) & Alw N1 & $\mathrm{CAGN}_{3} \mathrm{CTG}$ \\
\hline \multirow[t]{2}{*}{ K-ras } & GCA & GGT & CAA & GAG & - & $\begin{array}{l}\text { GCT GAT } \\
(59,60)\end{array}$ & $\mathrm{Bcl} \mathrm{I}$ & TGATCA \\
\hline & & & $\begin{array}{l}\text { CGA } \\
\text { CTA } \\
\text { CA } \\
\text { CAT }\end{array}$ & & & GAA (61) & $\begin{array}{l}\text { Ear I } \\
\text { Taq I } \\
\text { Xba I } \\
\text { Mae III } \\
\text { Nla III }\end{array}$ & $\begin{array}{l}\text { GAAGAG } \\
\text { TCGA } \\
\text { TCTAGA } \\
\text { GTCAC } \\
\text { CATG }\end{array}$ \\
\hline N-ras & GCT & GGA & CAA & GAA & GAG & GGC (60) & Bal I & TGGCCA \\
\hline
\end{tabular}

Sequence around codon 12 is shown; mutations are underlined. Mismatched nucleotide and its position in the primer is shown.

Origin of RFLP: Bcl I, Ear I, AlwNI, Bal I, Mitsudomi et al (reference 23); Nla III, Kumar et al (reference 24); Taq I, Xba I, Mae III, Milici et al (reference 25).

AlwNI, Bcl I, Nla III, Taq I, and Xba I from Sigma; Ear I from New England Biolabs.

Table 7 Cell lines used in the study

\begin{tabular}{ll}
\hline Cell line & Activating mutation and codon \\
\hline Calu I & TGT; K-ras codon 12 \\
A549 & AGT; K-ras codon 12 \\
SW480 & GTT; K-ras codon 12 \\
SW1116 & GET K-ras codon 12 \\
A427 & GAT K-ras codon 12 \\
T24 & Homozygous for valine at H-ras codon 12 \\
HT1080 & Homozygous for lysine at N-ras codon 61 \\
NCI-H1915 & CTG; H-ras codon 61 \\
NCI-H647 & GAC; K-ras codon 13 \\
\hline
\end{tabular}

Activating mutation underlined.

controls (Calu-1, SW 480, A427, SW1116, and T24 were purchased from ATCC, PHLS Centre for Applied Microbiology, Porton Down, Salisbury, UK) (table 7).

Codon 12 ras oncogenes

$H$-ras 12 -Primers were used to amplify H-ras codon 12 sequences spanning two endogenous MspI (CCGG) sites, one of which included the two target $G$ residues at position 12 and the other of which is an Msp1 control site. Positive control cell line material used in this assay was the T24 cell line (homozygous for the valine codon 12 mutation). The sizes of the undigested, normal, and mutant fragments are given in table 1.

K-ras 12 - This codon was amplified using a 5 ' end primer that contained a $\mathrm{C}$ substitution at the first position of codon 11 . This created a Bst N1 (CCTGG) site which overlaps the first two nucleotides of codon 12 . The 3 ' primer also contained a substitution, creating a control Bst N1 site. The cell line SW 480 was used as positive control material. The sizes of the undigested, normal, and mutant fragments are given in table 2 .

$\mathrm{N}$-ras 12 - In this case, by introducing an A residue at codon 13 through the mismatched antisense primer $\mathrm{N} 12 \mathrm{AHph}$, a novel $\mathrm{Hph}$ site was created. Any mutation abolished the restriction site. The sizes of the undigested, normal, and mutant fragment are given in table 3. Details of the RFLPs at codon 12 are given in table 4.

Codon 13 ras oncogenes

By introducing an A residue at codon 14 for ( $\mathrm{H}$ and $\mathrm{N}$ ras) and a $\mathrm{C}$ at codon 13 for $\mathrm{K}$ ras, screening for point mutations at codon 13 for each of the three ras oncogenes could be performed using the mismatched primers H13AHph, K13AHae, and N13AHph, which respectively created an $\mathrm{Hph} 1$ site for $\mathrm{H}$-ras, an Hae III site for K-ras, and an $\mathrm{Hph} 1$ site for $\mathrm{N}$-ras. Using the primers for K-ras codon 12 assay, the same amplified fragment can be digested with $\mathrm{Hph} 1$ to diagnose aspartic acid mutations at the second position of codon 13 . The particulars of the RFLPs are given in table 5 .

\section{Codon 61 ras oncogenes}

$H$-ras $61-$ For this codon, AlwN1 cut the fragment generated with primers H61AAlw and H61S (table 1) when no mutation was present. To maximise the efficiency of this assay, the entire codon was first amplified using H61S and H61A and a nested PCR for H61AAlw and H61S. The digestions are illustrated in tables 1 and 6.

K-ras 61-The enzyme Bcl I cut the PCR product amplified with $\mathrm{K} 61 \mathrm{SBcl}$ (which has two mismatches at codon 59 and 60) and K61A when the first two nucleotides of codon 61 are CA. The third nucleotide of codon 61 affects the genetic code, and Ear I digestion was therefore necessary. EarI would only cut the fragment generated by primers K61SEar and K61A when the third nucleotide of codon 61 was A. By combining the digestions of Bcl I and Ear I, any mutation could be detected. These digestions are illustrated in tables 2 and 6.

$N$-ras $61-\mathrm{Bal}$ I cut the fragment generated by N61SBal and N61A when the first two nucleotides were CA (table 6). Afl III will cut when codon 61 is CAT or CAC. Therefore when Bal I cuts and AflIII does not, then no activating mutation was present. The digestions are illustrated in tables 2 and 6. 


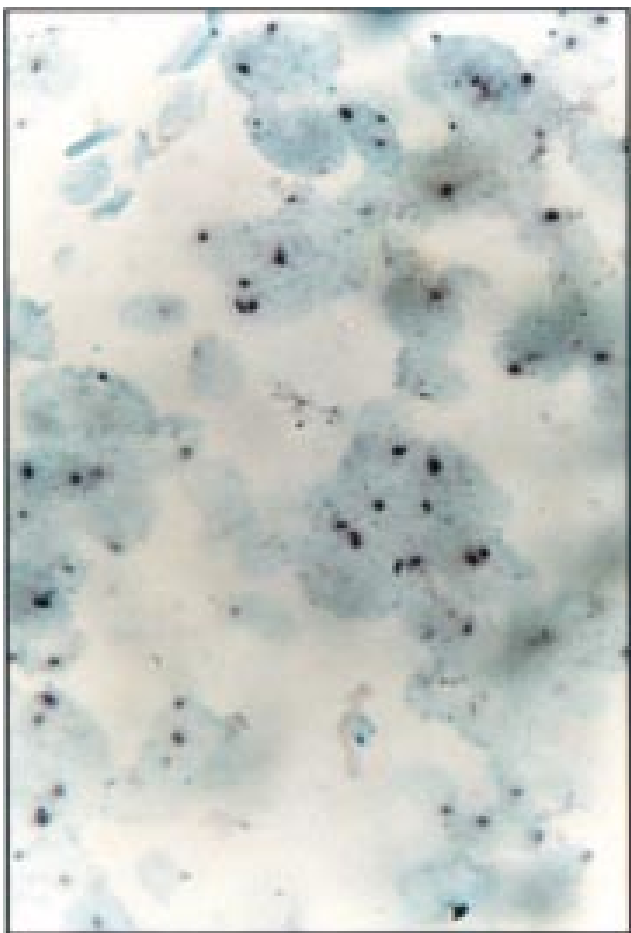

Figure 1 HPV 16 non-isotopic in situ hybridisation (NISH) assay in a cervical squamous cell carcinoma, showing punctate signals in the nuclei of many cells.

POLYMERASE CHAIN REACTION

Genomic DNA (100-500 ng) was amplified in a reaction volume of 50 or $100 \mu \mathrm{l}$ containing 50 $\mathrm{mM} \mathrm{KCl}, 10 \mathrm{mM}$ Tris- $\mathrm{HCl}$ (pH 8.3), $1.5 \mathrm{mM}$ $\mathrm{MgCl}_{2}, 0.01 \%$ (wt/vol) gelatin, $1.25 \mathrm{mM}$ of each of four dNTP, 50 pmol of primers, and 2.5 units of Taq DNA polymerase (Ampli Taq, Perkin-Elmer, Warrington, Cheshire, UK).

The conditions for the PCR using a 480 thermal cycler (Perkin-Elmer) were as follows: $94^{\circ} \mathrm{C}$ for five minutes for initial denaturation, 40 cycles of $94^{\circ} \mathrm{C}$ for one minute, annealing for two minutes, and extension at $68^{\circ} \mathrm{C}$ for two minutes.

Annealing temperatures were as follows: K-ras codon $12,45^{\circ} \mathrm{C}$; H-ras codon $12,62^{\circ} \mathrm{C}$; $\mathrm{N}$-ras codon $12,55^{\circ} \mathrm{C} ; \mathrm{K}$ - and $\mathrm{N}$-ras codons 13 and $61,50^{\circ} \mathrm{C}$; H-ras codon 13 and $61,60^{\circ} \mathrm{C}$.

Oligonucleotide primers were synthesised using a DNA synthesiser according to the published sequences data of the K-, H-, and N-ras genes. Primer sequences are shown in tables 1 , 2 , and 3 . In case of the H-ras codon 61 screening, the efficiency of PCR was very low because of two mismatches in the primer H61AAlw. To overcome this, we employed heminested PCR using entire exon II PCR product as a template for second stage PCR.

RESTRICTION ENZYME DIGESTION AND GEL ELECTROPHORESIS

PCR product $(16-20 \mu \mathrm{l})$ was digested with the restriction enzymes shown in tables $1-3$. The reaction conditions followed suppliers' recommendations. DNA was electrophoresed through $4-6 \%$ agarose gels, followed by ethidium bromide staining. Gels were photographed using an ultraviolet light transilluminator.

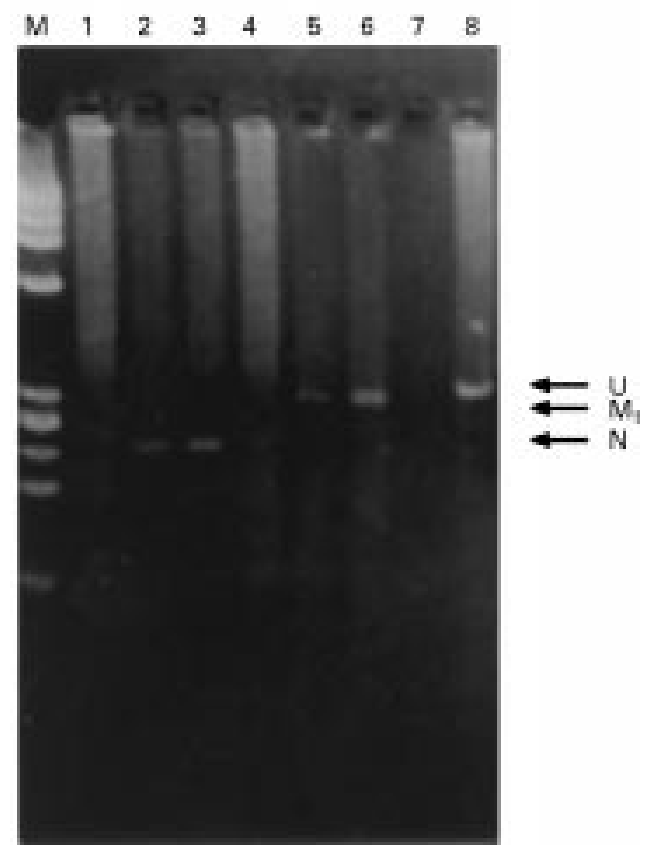

Figure 2 H-ras 12 mutation PCR/RFLP assay, using a $4 \%$ agarose gel. Marker ladder used is phi X174. U, uncut amplified product; $M t$, mutant fragment (lane 6). Lane 5 shows mutated H-ras codon 12 in a tumour sample.

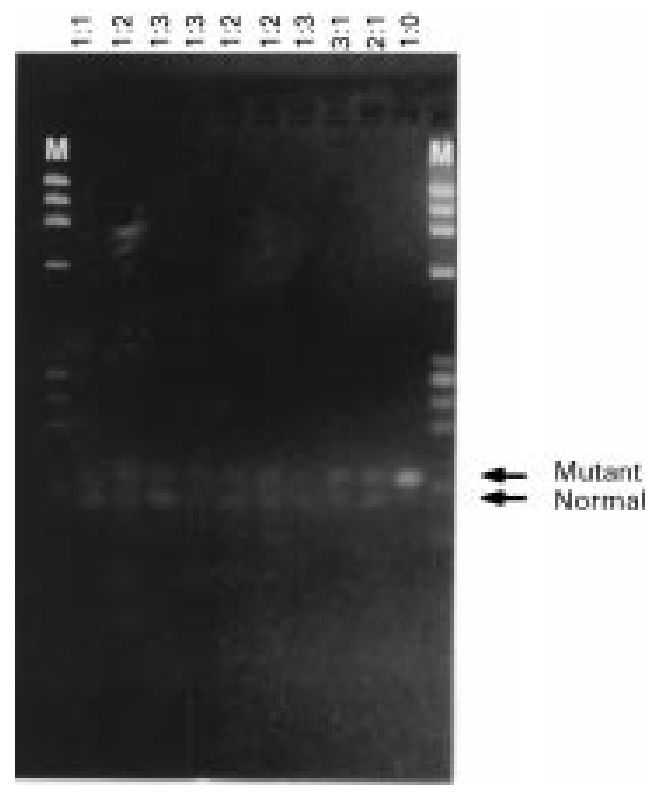

Figure $3 N$-ras codon 61 assay to establish PCR/RFLP assay sensitivity: $25 \mathrm{ng}$ of starting DNA template was used; genomic DNA was prepared from HT 1080 cells

(homozygous for the mutant 61 lysine allele). This mutant DNA was mixed with normal genomic DNA obtained from human placenta and mixed in defined ratios. The amplified product was then digested with Bal I.

\section{Results}

Of the 20 CIN IIIs examined, 19 contained HPV 16 DNA sequences by PCR and NISH. Dual infection was not uncovered. The 20 early (stage I and II) invasive squamous cell carcinomas showed predominant HPV 16 positivity $(17 / 20)$ with one case $(1 / 20)$ being HPV 18 positive, again confirmed on PCR and NISH (fig 1).

Activating mutations were not identified in any of the CIN samples. Only one stage I HPV 
16 positive carcinoma showed an activating mutation at codon 12 of H-ras. The adjacent normal ectocervical mucosa from the same patient was normal. All control cell lines yielded restriction patterns as predicted (fig 2). The sensitivity of the assay with loading contaminating non-mutated DNA was also established (fig 3) at a sensitivity of 1:3 (tumour to contaminating DNA sequences) using $25 \mathrm{ng}$ of starting DNA template (fig 3), and 1:4 and 1:5 using higher DNA concentrations $(100-500 \mathrm{ng})$. Control DNA from normal cervical margins did not reveal any activating mutations.

\section{Discussion}

We examined 20 CIN III samples (19 HPV positive, one HPV negative) and 20 stage I and II cervical carcinomas (18 HPV positive, two HPV negative) to assess the prevalence of point mutations in $\mathrm{H}, \mathrm{K}$, and $\mathrm{N}$-ras oncogenes, using a PCR/RFLP analysis. This assay offers a rapid, non-radioactive method of screening ras mutations in large study populations.

The optimal digestion conditions for RFLP analysis were first established using positive control cell lines containing defined activating mutations. We were confidently able to demonstrate mutant DNA in a $1: 3$ ratio in contaminating normal DNA, even using $25 \mathrm{ng}$ of starting DNA template (fig 3). At higher starting DNA concentrations, ratios of 1:4 were easily achieved.

We identified an activating mutation at codon $12 \mathrm{H}$-ras in one HPV 16 positive stage I cervical squamous cell carcinoma. The surrounding normal ectocervical mucosa in this patient did not contain any activating mutation. No adjacent CIN III was identified in this case.

The findings are in keeping with those of Bos, ${ }^{2}$ but are contrary to the findings of Riou et $a l,{ }^{12}$ in which mutations at codon 12 of H-ras were found in $24 \%$ of tumours at an advanced stage. Additionally $40 \%$ of tumours with mutations (in the Riou series), also contained an allelic deletion at that locus. Riou's data suggest that deletions and mutations of H-ras gene occur in advanced stages of cervical carcinoma. The tumours examined in our study were predominantly stage I and II-a different study group where different genetic events may be operational.

Previously, Rumsby et al found a low incidence of ras oncogene activation in a range of human squamous cell carcinomas. ${ }^{16}$ Hiorns et al screened a series of anogenital tumours for activating mutations of the ras oncogene family using the polymerase chain reaction and a series of synthetic oligonucleotide probes ${ }^{17}$ (an alternative method to the assay adopted in our study). Mutations were seen in only two cases (both K-ras codon 12), neither of which was $\mathrm{HPV}$ associated. Their findings readily suggest that ras activation does not appear to be a common event in the genesis of these tumours and when it did occur it did not appear to coexist with HPV infection. This supports the findings of our study, in which the majority of cases were HPV positive and activating ras mutation negative. It seems likely, therefore, that in early anogenital neoplasia mutations at either codon 12 of H-ras and K-ras in particular are uncommon events.

Our data in relation to CIN III are in accordance with those of Le Van et al, ${ }^{26}$ who were unable to identify $\mathrm{H}$-ras 12 mutations in cases of CIN I, II, and III. However, Grendys et al have recently demonstrated mutations in $\mathrm{Ha}$, $\mathrm{Ki}$, and N-ras codon 61 in $24.2 \%$ of stage IB cervical carcinomas, ${ }^{27}$ contrasting with $5 \%$ $(1 / 20)$ in our study.

In conclusion, ras activation does not appear to occur in conjunction with HPV infection, particularly of HPV 16 infected high grade cervical intraepithelial neoplasia. In addition, ras activation is an infrequent event in early squamous cell carcinoma, although the interaction of HPV 16 and ras oncogenes in cellular transformation in vitro has been shown. ${ }^{28}$ This leads us to believe that many different cell types differ in their susceptibility to transformation by such agents.

On current data, the postulated model of HPV linked carcinogenesis suggests malfunctional control of HPV transcription as a necessary component for neoplastic progression. It is also clear, however, that host gene alterations are equally necessary for HPV linked carcinogenesis to occur.

1 Marshall CJ. Human oncogenes. In: Weiss R, Teich N, Varmus $\mathrm{H}$, Coffin $\mathrm{J}$, eds. RNA tumour viruses. Cold Spring Harbor: Cold Spring Harbor Press, 1985:487-558.

2 Bos JL. The ras gene family and human carcinogenesis. Mutat Res 1988;195:255-71.

3 Barbacid M. ras Genes. Annu Rev Biochem 1987;56:779827 .

4 Gilman AG. G proteins and dual control of adenylate cyclase. Cell 1984;36:577-9.

5 Gibbs JB, Sigal IS, Poe M, et al. Intrinsic GTPase activity distinguishes normal and oncogenic ras p 21 molecules. Proc Natl Acad Sci USA 1984;81:5704-8.

6 Manne V, Bekesi E, Kung HF. Ha-ras proteins exhibit GTPase activity: point mutations that activate $\mathrm{H}$-ras gene product result in decreased GTPase activity. Proc Natl Acad Sci USA 1985;82:376-80.

7 Walter $M$, Clark SG, Levinson AD. The oncogenic activation of human $\mathrm{p} 21$ ras by a novel mechanism. Science 1986;233:649-52.

8 Westaway D, Papkoff J, Moscovici C, et al. Identification of a pro-virally activated c-Ha-ras oncogene in an avian nephroblastoma via a novel procedure: CDNA cloning of a chimaeric viral-host transcript. EMBO f 1986;5:301-9.

9 Pulciari S, Santos E, Long LK, et al. ras Gene amplification Pulciari S, Santos E, Long LK, et al. ras Gene amplification
and malignant transformation. Mol Cell Biol 1985;5:2836841

10 Cichutek K, Duesberg PH. Harvey ras genes transform without mutant codons apparently activated by truncation of 5' exon (exon-1). Proc Natl Acad Sci USA 1986;83:23404.

11 Riou G, Barrois M, Sheng ZM, et al. Somatic deletions and mutations of c-Ha-ras gene in human cervical cancers. Oncogene 1988;3:329-33.

12 Riou G, Barrois M, Dutronquay V, et al. Presence of papillomavirus DNA sequences, amplification of c-myc and c-Ha-ras oncogenes and enhanced expression of c-myc in c-Ha-ras oncogenes and enhanced expression of c-myc in and Clinical Aspects 1985;47-56.

13 Agnantis NJ, Spandidos DA, Mahera H, et al. Immunohistochemical study of ras oncogene expression in endometrial and cervical human lesions. Eur f Gynecol Oncol 1988;9: and cervic 5 .

14 Kitchener HC. Recent developments in viruses and genetics in gynaecologic cancer. Curr Opin Oncol 1990;2:864-9.

15 Enomoto T, Inoue M, Perantoni AO, et al. K-ras activation in neoplasms of the human female reproductive tract. Cancer Res 1990;50:6139-45.

16 Rumsby G, Carter RL, Gusterson BA. Low incidence of ras oncogene activation in human squamous cell carcinomas. Br F Cancer 1990;61:365-8.

17 Hiorns LR, Scholefield JH, Palmer JG, et al. Ki-ras oncogene mutations in non-HPV associated anal carcinoma. 7 Pathol 1990;161:99-103.

18 Victor T, Du Toit R, Jordaan AM, et al. No evidence for point mutations in codons $12,13,61$ of the ras gene in a high incidence area for esophageal and gastric cancers. Cancer Res 1990;50:4911-14. 
19 O'Leary JJ, Browne G, Crowley M, et al. Non-isotopic detection of DNA in tissues. In: Herrington CS, Levy BR, eds. In-situ hybridisation. A practical approach. Oxford: Oxford University Press, 1994:51-83.

20 Arends MJ, Donaldson YK, Duvall E, et al. HPV in full thickness cervical biopsies: high prevalence in CIN2 and CIN3 detected by a sensitive PCR method. F Pathol 1991; 165:301-9

21 Van den Brule AFC, Snijders PJF, Gordijn RLJ, et al. General primer-mediated polymerase chain reaction permits the detection of sequenced and still unsequenced human papillomavirus genotypes in cervical scrapes and carcinomas. Int $\mathcal{f}$ Cancer 1990;45:644-9.

22 Kahn SM, Jiang W, Weinstein IB. Rapid non-radioactive detection of ras oncogenes in human tumours. Amplifications: A Forum for PCR Users 1990;4:22-6.

23 Mitsudomi T, Viallet J, Mulshine JL, et al. Mutation of ras genes distinguish a subset of non- small-cell lung cancer cell lines from small-cell lung cancer cell lines. Oncogene 1991;6:1353-62.

24 Kumar K, Dunn LL. Designed diagnostic restriction fragment length polymorphisms for the detection of point mutations in ras oncogenes. Oncogene Res 1989;4:235- 41.

25 Milici A, Blich M, Murphy E, et al. c-K-ras codon 12 GGTCGT point mutation. An infrequent event in human lung cancer. Biochem Biophys Res Commun 1986;140:699-705.

26 Le Van L, Stoerker J, Rinehart CA, et al. H-ras codon 12 mutation in cervical dysplasia. Gynecol Oncol 1993;49:181mutati

27 Grendys EC, Barnes WA, Weitzel J, et al. Identification of $\mathrm{H}$, $\mathrm{K}$ and $\mathrm{N}$-ras point mutations in stage IB cervical carcinoma. Gynecol Oncol 1997;65:343-7.

28 Matlashewski G, Schneider J, Banks L, et al. Human papillomavirus type $16 \mathrm{DNA}$ co-operates with activated ras in transforming primary cells. EMBO f 1987;6:1741-6. 